\title{
Public-private partnership conceptual framework and models for the funding and financing of water services infrastructure in municipalities from selected provinces in South Africa
}

\author{
Cornelius Ruiters ${ }^{1,2 *}$ and Maselaganye P Matji, ${ }^{1,2}$ \\ 'Council for Scientific and Industrial Research (CSIR), Built Environment, P.O. Box 395, Pretoria, 0001, South Africa \\ ${ }^{2}$ University of South Africa, Graduate School of Business Leadership, P.O. Box 392, UNISA, 0003, South Africa
}

\begin{abstract}
This paper presents public-private partnership (PPP) framework models for funding and financing of water services infrastructure at local government (municipalities) level (sphere) in South Africa. Data were assembled from various stakeholders, viz., private and public sector institutions in the Gauteng and Limpopo Provinces of South Africa. The framework for PPPs identified three models, viz. state, hybrid and private sector models. In the 'state model' the water services value chain is $100 \%$ government funded and owned infrastructure. Government is a key player in infrastructure investment and inefficiencies within the public expenditure management systems are particularly detrimental, e.g., there are significant problems in spending of infrastructure budgets. In the 'private model' harnessing the significant potential for capital markets to finance water infrastructure, particularly local bond markets, is contingent on their strengthening and further development. Well-functioning and appropriately institutional investors (pension funds, insurance companies, etc.) would be natural sources of long-term financing for water services infrastructure because liabilities would better match the longer terms of water infrastructure projects. The 'hybrid model' is in the middle of the water services value chain, i.e., a partnership between government and the private sector. The use of this framework is essential in the including of the private sector in the implementation of water infrastructure development projects. The research results highlight the underlying principles that underpin, support, determine and confirm the success of the PPP models and value chain framework for local government water infrastructure in South Africa. Twelve key parameters were identified that would drive the success of any water services infrastructure PPP model. Even though PPP is an alternative procurement vehicle, PPP models are considered to be used as vehicles for addressing institutional challenges in local government. However, in most cases it has been indicated that lack of technical and financial skills and monitoring of the private operator are serious challenges.
\end{abstract}

Keywords: financing, funding, Gauteng and Limpopo Provinces, PPP framework, PPP models, water services infrastructure

\section{INTRODUCTION}

Many developing countries need water infrastructure to improve the livelihoods of their citizens and their quality of life, and South Africa is no exception. While there are many constraints to the delivery of water services infrastructure, one of the most obvious factors that hampers delivery is project costs. Access to finance is the lifeblood of water services infrastructure delivery, as is the packaging of the funding model for each project or groups of projects. Unfortunately, the cost of water services infrastructure delivery continues to escalate to the point where many developing countries simply cannot afford such infrastructure.

The backlog of water infrastructure provision and poor access to service delivery for poor communities have forced a new approach for governments, industries, financiers and other role players. Delays escalate the eventual cost of infrastructure even more. Countries like South Africa have no choice but to look at innovative approaches, such as public-private partnerships (PPP) models, to ensure that they eliminate their water infrastructure backlogs. Efficient and productive water services infrastructure are important inputs for all industries and hence vital for economic growth and efficiency, productivity and competitiveness. Continued growth in infrastructure

\footnotetext{
* To whom all correspondence should be addressed.

e-mail: CRuiters@csir.co.za

Received: 13 June 2014; accepted in revised form 16 March 2016
}

productivity will play a crucial role in managing the emerging challenge of South Africa's growing population (DBSA, 2009; DWAF, 2004, 2008).

The Department of Water Affairs (DWA, now the Department of Water and Sanitation) traditionally funded water infrastructure development projects in South Africa (DWAF, 2003, 2004, 2008; DBSA, 2009; Moseki et al., 2011; Ruiters, 2011). With the growing demands on water infrastructure, no appropriate and alternative analyses and models have since been proposed and finalised. There is therefore pressure to consider alternative funding models for improved water services infrastructure management, particularly by investigating relevant PPP funding models (World Bank, 1994; Matta and Ashkenas, 2003; ADB, 2008; Ruiters, 2011, 2013; Matji, 2013; Matji and Ruiters, 2015a, b).

Municipalities (with water services authority status) are facing various challenges such as the lack of technical, planning and management skills, limited financial resources, and lack of operation and maintenance resulting in dilapidating and aging water and sanitation services infrastructure. There has been rapid decentralisation of the responsibility for the provision of water services (water and sanitation), with massive spending and development to achieve universal access, which has occurred in tandem with massive changes (transformation) in the form and function of local government (DPLG, 2000a, 2000b; DWAF, 1997a, 1997b, 2003; NT, 2003, 2013c; DCoG, 2010; Eales, 2011). The role of local government has been fundamentally reconceived and reconfigured as the primary driver and enabler of 
development, i.e., water services (DPLG, 2000a, 2000b; DWAF, 1997a, 1997b, 2003; NT, 2003, 2013c; DCoG, 2010; Eales, 2011). Municipalities (with water services authority status) have to find creative and innovative models that can assist in responding to water services infrastructure delivery needs. In South Africa, a few municipalities contracted private sector operators during the 1990s under lease or concession contracts (Marin et al., 2009). The primary objectives of this research were: (i) to develop a public-private partnership (PPP) conceptual framework; (ii) the identification and review of PPP models for funding and financing of water services infrastructure at local government (municipalities) level (sphere) in South Africa; and (iii) to determine key principles and parameters (variables) that should inform the development of a cost-effective PPP model to ensure sustainability of local government water infrastructure.

\section{METHODS}

\section{Data collection}

The primary and secondary data collection methods for the research involved the following (Coldwell and Herbst, 2004; Tustin et al., 2005):

\section{Primary data}

Data were collected from a sample of 24 participating water sector organisations using a Likert scale questionnaire and the purposive sampling method. Homogeneous sampling as a purposive sampling technique was used to achieve a homogeneous sample; that is, a sample whose units (e.g., people, cases, etc.) share the same (or very similar) characteristics or traits (e.g. group(s) of people that are similar in terms of background, occupation, etc.). Participants were chosen to represent a homogeneous sample since the research questions were specific to the characteristics of the particular group of interest. Participants included officials and politicians from municipalities in the study area (Gauteng and Limpopo Provinces of South Africa), Rand Water, Umgeni Water, Magalies Water, Johannesburg Water, East Rand Water Care Company (ERWAT), local and international private companies with an interest in water and sanitation infrastructure within and outside the study area, the Development Bank of Southern Africa, officials from the national Department of Water Affairs (now the Department of Water and Sanitation), National Treasury and water user associations operating in the study area. The sample represented individuals with special technical and financial expertise and knowledge of water infrastructure finance, planning, development, policy and regulation.

The primary data were collected from the Gauteng and Limpopo Provinces by questionnaire (Appendix 1). These two provinces were selected for primary data collection since most of the PPP contracts/agreements were concluded and are operating in a number of municipalities (water services authorities) within them. Data were assembled in the period May-August 2013. Methods that were used to assemble the data included:

- E-mail correspondence with participants. Some participants compiled a comprehensive write-up of their views by e-mail. This was over and above questions raised in the questionnaire.

- One-on-one interviews with participants. Meetings were arranged to present completed questionnaires and provided an opportunity to ask more questions and assemble additional data.
- Group discussions on and debates on public-private partnerships (PPP). This implies that responses presented were a consolidation of different views, ideas, perceptions and understanding of public-private partnerships.

\section{Secondary data}

Reviewed reports relating to water services infrastructure needs and funding in the Gauteng and Limpopo Provinces, and additional research information on water services PPP funding models were obtained from case studies in other provinces (DCoG, 2010; DWA, 2010, 2011, 2012a, 2012b, 2012c, 2013; NT, 2011a, 2011b, 2011c, 2011d, 2013a, b, c, d). Data obtained from physical documentation were also provided by some of the participants.

\section{Statistical analysis}

For the quantitative data analysis, (i) nominal (categorical); and (ii) ordinal (ranked) data (scales) types were considered and used, where appropriate (cf. Taylor, 2002; Coldwell and Herbst, 2004; Tustin et al., 2005). The non-parametric chi-square $\left(\chi^{2}\right)$ test statistic was used to determine whether dependency (or contingency) exists between the PPP models key financial variables (i.e. awareness, success, appropriateness, (economic) viability and attractiveness) and evaluation criteria (i.e. strongly agree, agree, neutral, disagree and strongly disagree) identified from the primary data collection ( $c f$. Coldwell and Herbst, 2004; Tustin et al., 2005). The arcsine $\sqrt{x}$ was used for the data transformation before application, where appropriate (cf. Tustin et al. 2005).

\section{RESULTS AND DISCUSSION}

\section{Public-private partnership (PPP) value chain framework models}

The results of the study identified three overarching models within the PPP value chain framework (Fig. 1):

- State model: The water services value chain is $100 \%$ government funded and owned infrastructure. Government is a key player in infrastructure investment and inefficiencies within the public expenditure management systems are particularly detrimental, e.g., there are significant problems in spending of infrastructure budgets (DCoG, 2010; NT, 2011d, 2013b, c; DWA, 2012a).

- Private model: The other extreme of the water services value chain is $100 \%$ private sector funded and owned infrastructure. Harnessing the significant potential for capital markets to finance water infrastructure, particularly local bond markets, is contingent on their strengthening and further development. Well-functioning and appropriately institutional investors (pension funds, insurance companies, etc.) would be natural sources of long-term financing for water services infrastructure because liabilities would better match the longer terms of water infrastructure projects (cf. Inderst, 2009; World Bank, 2010; TCTA, 2012).

- Hybrid model: In the middle of the water services value chain is a hybrid model, i.e., between government and the private sector. An institutional framework was developed to guide this type of development (NT, 2000; OECD, 2008, 2010, 2012; DCoG, 2010). The use of this framework is essential in including the private sector in the implementation of water infrastructure development projects 


\section{PUBLIC PRIVATE PARTNERSHIP VALUE CHAIN}

\section{Framework for Public Private Partnerships}

\begin{tabular}{|c|c|c|}
\hline \begin{tabular}{l}
\multicolumn{1}{c}{ State Model } \\
- State funding (100\%) \\
Infrastructure ownership by the \\
state (100\%) \\
Infrastructure operations and \\
maintenance by the state \\
Private sector employed only as \\
consultants \\
Government own skills base \\
- Private sector retain its own skills \\
base to maximize revenue and \\
financial sustainability \\
Inefficient and prolonged projects \\
(scope creep of projects) \\
Ineffective costing of projects - \\
benefit to private sector or \\
consultants \\
State both a referee and player
\end{tabular} & $\begin{array}{l}\text { Hybrid Model } \\
\text { - Mixed funding between the state } \\
\text { and private sector } \\
\text { - Infrastructure ownership by the } \\
\text { state } \\
\text { - Infrastructure maintenance } \\
\text { outsourced } \\
\text { - There is knowledge and skills } \\
\text { transfer between the private and } \\
\text { public sectors } \\
\text { - Room for innovation and creativity } \\
\text { - State focusses on the regulation of } \\
\text { the private sector } \\
\text { Operational efficiency and cost } \\
\text { optimisation are achieved } \\
\text { Projects are completed within } \\
\text { scope, on time and within budget }\end{array}$ & $\begin{array}{l}\text { Private Model } \\
\text { - Private funding (100\%) } \\
\text { Private ownership of the } \\
\text { infrastructure (100\%) } \\
\text { - Private sector carries the full costs } \\
\text { and risks of the projects } \\
\text { - State plays an effective regulator in } \\
\text { the interest of consumers and } \\
\text { users (public interest) } \\
\text { - Private sector retains skills to } \\
\text { maximize revenue, profits and } \\
\text { future business (sustainability) } \\
\text { Strategic social infrastructure, i.e. } \\
\text { water, energy, sanitation, etc., are } \\
\text { controlled by the private sector }\end{array}$ \\
\hline
\end{tabular}

Figure 1

Public-private partnership value chain framework and models for water services infrastructure from data collected in the Limpopo and Gauteng Provinces of South Africa

(NT, 2000, OECD, 2012). Meaningful involvement by the private sector is, however, not automatic but subjected to important prerequisites for such financing, i.e., political commitment, enabling legislation, evaluation framework, expertise, project prioritisation, risk management, and standardisation (RCCAO, 2006; Sihombing, 2008; OECD, 2008, 2010, 2012; ADB, 2008; Rowey, 2009; Laitinen et al., 2010; Leach, 2010; UNESCAP, 2011; KPMG, 2011; MOF, 2012).

In addition, the research results highlight the following underlying principles that underpin, support and determine the above-mentioned overarching PPP value chain framework derived from the selected municipalities within the Gauteng and Limpopo Provinces in South Africa (cf. Table 1; NT, 2000; ADB, 2008; MOF, 2012; OECD, 2012):

- Comprehensive feasibility study: Any PPP contract should be informed by an in-depth analysis of the technical, financial, social and legal aspects of the project.

- Contract management regime: PPP contracts are managed as part of the project planning process.

- Long-term contractual arrangement compliance: A municipality must adhere to due processes; however, the contract should be reviewed every 3 years.

- PPP contractual arrangements: must be carefully scrutinised prior to finalisation to ensure that the consumer's interest is protected. PPP contracts must adhere to a social and commercial balance.

- PPP contracts: Approvals should be centralised and managed by the National Treasury to minimise potential abuse and promote competitive advantages.

- Assessments and/or due diligence: Based on the current trends private sector institutions approach municipalities to negotiate PPP contracts instead of them taking a decision on whether the infrastructure challenges should be addressed through PPP contracts.

- Timeframe of PPP arrangements: Municipal officials and politicians must take into account that PPP arrangements will only make sense if the contract is long-term (e.g. > 10 years).

- Strong enforcement of regulations for all PPP contracts: There seems to be little or no support for effective regulation of PPP arrangements. In local government, a shortage of technical and management skills makes it more difficult for PPP contracts to be managed or monitored.

- Revenue flows or ability to recover the debt quicker: The length of the PPP contracts should enable municipalities to recover debt over a shorter timeframe. This implies that the contract be structured in such a way that there is no penalty for early settlement of the debt.

\section{Comparative assessment of PPP governance models}

The conceptual PPP value chain framework model parameters derived from the results are presented. Some $50 \%$ of the respondents were aware of the PPP models for the delivery of water services infrastructure in the study area, whereas about $67 \%$ of the respondents were aware of the existence of PPP models in the water sector and other sectors of the economy (Fig. 2). Furthermore, 12 key parameters were identified that would drive any water services infrastructure PPP model (Table 1). PPP models allow the public and private sectors to forge efficient partnerships and enable a robust pipeline of economic water services infrastructure to be built around the country without delay. From the results it was found that approximately $65 \%$ of the participants agreed that PPP contractual arrangements that they are aware of are yielding desired results (Fig. 3). However, it does not necessarily mean that there are not challenges with such PPPs. Some $22 \%$ of the participants who expressed a neutral view believed that current challenges in some of the PPPs are serious and could derail the PPP arrangements if they are not addressed. After the introduction of the National Free Basic Water Policy (DWAF, 2003), the culture of payment for services declined. Consequently, this led to the renegotiation of the concessionaire 


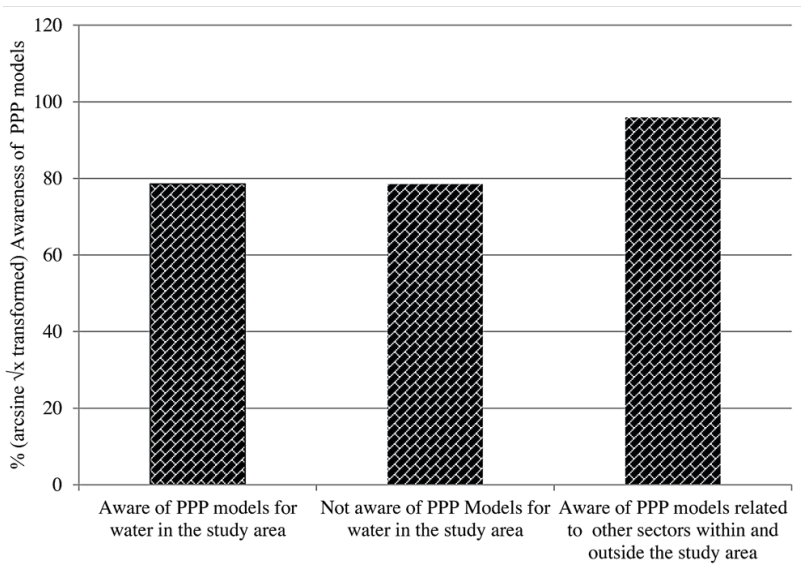

Figure 2

Percentage awareness (arcsine $\sqrt{ } x$ transformed) of PPP models for water services infrastructure delivery at local government level in the Gauteng and Limpopo Provinces of South Africa

to shift the risk back to municipalities (Bender and Gibson, 2010). New elements that were incorporated as an addendum to the original contract were: (i) exemption from committing further investment of concessionaire's own funds; (ii) receive operating subsidies as partial payment for unpaid bills as well as capital subsidies for infrastructure investment in previously underserved areas; and (iii) eliminating of large annual payments to the municipalities. In addition, there is no strong contract management by municipalities due to lack of technical skills. Importantly, these types of PPP models allow the public sector to provide capital that can also earn a potential return and is recycled (cf. Lang and Merion, 1993; AASHTO, 1995; Goodman and Hastak, 2006; ADB, 2008). The PPP models are typically a variation of the design-build-finance-operate (DBFO) model or the design-build-operate (DBO) model (NT, 2000; ADB, 2008; OECD, 2008, 2010, 2012; MOF, 2012):

- Design-build-finance-operate (DBFO) model - the most common form of PPP, involving the integration of these four functions, design, build, finance and operate, within one PPP service provider. The PPP provider will secure its own financing to build, maintain and operate the facilities to meet the public sector's requirements.

- Design-build-operate (DBO) model - the public sector provides the funds for the design and building of the facility, and then continues to engage the same private vendor to operate the facility. The operator is then paid a management fee according to performance standards. This model may be suitable for very large projects which the private sector is unable to finance wholly.

Even though PPP is an alternative procurement vehicle, about $54 \%$ of the participants agreed that PPP models can also be used as vehicles to address institutional challenges in local government (Fig. 4). In most of the case studies considered in this research, PPP models are managed through service level agreements or memoranda of understanding between the government institution and a private company. However, in most cases it has been indicated that lack of technical skills and monitoring of the private operator are serious challenges (Bender and Gibson, 2010). All municipalities in the study area engage private sector institutions through an open tender system. In such cases, the full project, technical, financial, legal and contractual risks reside with the municipality, i.e., the state model. In this type

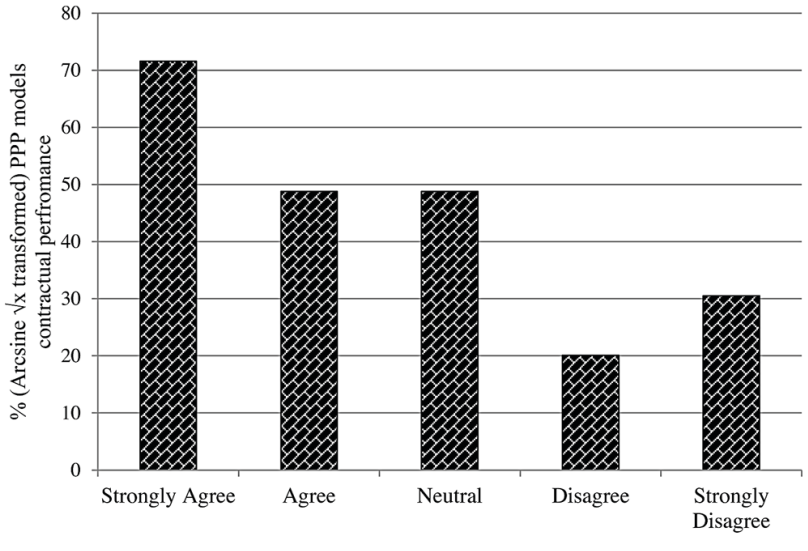

Figure 3

Percentage (arcsine $\sqrt{x}$ transformed) of respondents agreeing/ disagreeing on the performance of contractual arrangements for PPP models at local government in the Gauteng and Limpopo Provinces of South Africa

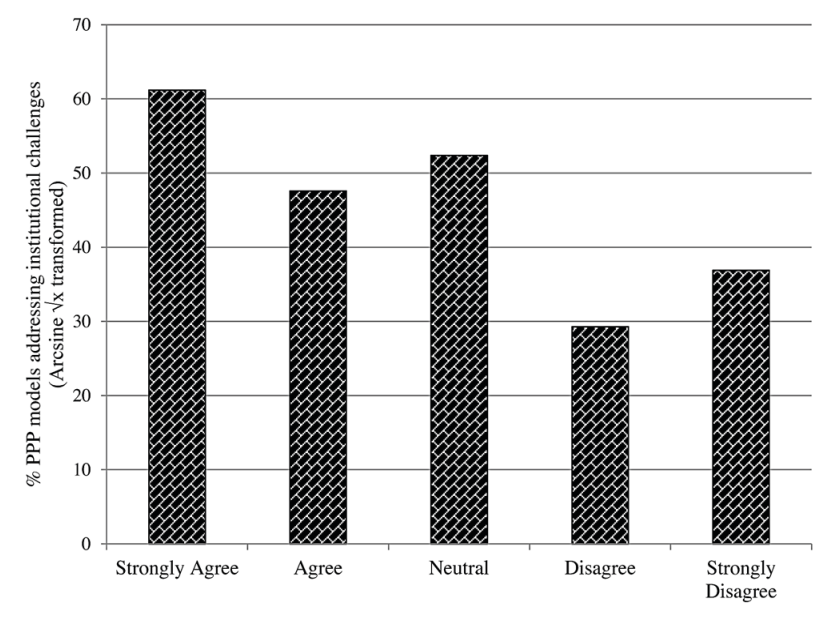

Figure 4

The extent to which participants agree/disagree (arcsine $\sqrt{x}$ transformed) that PPP governance models address institutional arrangements at local government

of arrangement, there is no incentive for the transfer of skills, creativity and innovation to achieve operational efficiency.

These results and case studies from the Gauteng and Limpopo Provinces have confirmed that well-structured PPP models for water and sanitation infrastructure can be a success, on condition that there are sufficient revenue streams and the contract suits all parties involved (cf. Moleke, 2000; ADB, 2008; Bender and Gibson, 2010; OECD, 2010; KPMG, 2011; Matji, 2013). In general, municipalities need education, awareness and training on the functions, benefits, challenges and other implications of PPP models. Lack of technical, management and legal capacity of municipalities make it difficult for PPP models to be successfully implemented in local government. Even though the results have indicated that investors or financiers have interest in local government water infrastructure, lack of technical oversight remains a challenge. In order to gain maximum benefit from all PPP arrangements across the water sector or other sectors, approval and finalisation of PPP contracts should be centralised. The National Treasury's Public Private Partnership 
TABLE 1

Comparison of PPP models in terms of 12 parameters for water services infrastructure delivery at local government in the Gauteng and Limpopo Provinces of South Africa

\begin{tabular}{|c|c|c|c|c|}
\hline No. & $\begin{array}{l}\text { Model } \\
\text { parameters }\end{array}$ & Parameters of the State Model & Parameters of the Hybrid Model & $\begin{array}{l}\text { Parameters of the Private } \\
\text { Sector Model }\end{array}$ \\
\hline 1 & $\begin{array}{l}\text { Technical/ } \\
\text { project risk }\end{array}$ & $\begin{array}{l}100 \% \text { of the technical and project risk } \\
\text { is carried by the state. }\end{array}$ & $\begin{array}{l}\text { There is shared risk between the } \\
\text { state and private sector. The range is } \\
\text { between } 10 \% \text { and } 90 \% \text {. }\end{array}$ & $\begin{array}{l}100 \% \text { of the risk is carried by the } \\
\text { private sector. }\end{array}$ \\
\hline 2 & Financial risk & $\begin{array}{l}100 \% \text { of the risk is carried by the } \\
\text { state. The state funds everything. }\end{array}$ & $\begin{array}{l}\text { The risk is shared by both the state } \\
\text { and private sector institution. The } \\
\text { range is between } 10 \% \text { and } 90 \% \text {. }\end{array}$ & $\begin{array}{l}100 \% \text { of the risk is carried by the } \\
\text { private sector. Private sector funds } \\
\text { everything. }\end{array}$ \\
\hline 3 & Contractual risk & The state carries the full risk. & The risk is shared by both parties. & $\begin{array}{l}\text { The private sector carries the full } \\
\text { risk. }\end{array}$ \\
\hline 4 & $\begin{array}{l}\text { Skills and } \\
\text { knowledge } \\
\text { transfer }\end{array}$ & $\begin{array}{l}\text { Private sector will not prefer trans- } \\
\text { ferring skills and knowledge to } \\
\text { government officials because it might } \\
\text { put them out of business. }\end{array}$ & $\begin{array}{l}\text { Transfer of skills and knowledge can } \\
\text { easily be enforced and there will be } \\
\text { willingness from the private sector. }\end{array}$ & $\begin{array}{l}\text { Private sector prefers to retain skills } \\
\text { to maintain competitive advantage. }\end{array}$ \\
\hline 5 & $\begin{array}{l}\text { Roles and } \\
\text { responsi- } \\
\text { bilities of state } \\
\text { institutions }\end{array}$ & $\begin{array}{l}\text { Implementation of local government } \\
\text { infrastructure is the mandate of local } \\
\text { authorities. Section } 152 \text { (b) of the } \\
\text { Constitution of the Republic of South } \\
\text { Africa. National Departments and state } \\
\text {-owned entities support local govern- } \\
\text { ment (section } 154 \text { (1) of the Constitution } \\
\text { of the Republic of South Africa). } \\
\text { National government can easily be } \\
\text { caught in conflicting roles of imple- } \\
\text { mentation, policy-making, and } \\
\text { regulation. }\end{array}$ & $\begin{array}{l}\text { Local government remains the } \\
\text { implementer but with the support of } \\
\text { private sector institutions and state- } \\
\text { owned entities. } \\
\text { Strong and independent water sector } \\
\text { regulator is required. }\end{array}$ & $\begin{array}{l}\text { Private sector implements on behalf } \\
\text { of local government. } \\
\text { Very strong and independent water } \\
\text { sector regulator is required. }\end{array}$ \\
\hline 6 & $\begin{array}{l}\text { Affordability } \\
\text { and revenue } \\
\text { flows }\end{array}$ & $\begin{array}{l}\text { Heavy reliance on government } \\
\text { grants. Some schemes imple- } \\
\text { mented with appropriate revenue } \\
\text { flow and affordability assessments. } \\
\text { Sustainability of infrastructure } \\
\text { becomes a serious challenge. }\end{array}$ & $\begin{array}{l}\text { Affordability and revenue flows are } \\
\text { prioritised, because these might } \\
\text { have a negative effect on business } \\
\text { operations. Proper assessments are } \\
\text { conducted prior to full-scale pro- } \\
\text { ject implementation. Private sector } \\
\text { invests on the basis of government } \\
\text { subsidy to either capital or revenue. }\end{array}$ & $\begin{array}{l}\text { Affordability and revenue flows are } \\
\text { of highest priority. Private sector } \\
\text { invests on the basis of return on } \\
\text { investment or return on equity. }\end{array}$ \\
\hline 7 & Value for money & $\begin{array}{l}\text { There is a high chance of financing } \\
\text { operational inefficiencies in the system. } \\
\text { There are limited chances that consult- } \\
\text { ants or service providers will focus } \\
\text { on value for money when supporting } \\
\text { government. Operational efficiency } \\
\text { and cost optimisation is of highest } \\
\text { priority. The intention is to maximise } \\
\text { profits and reward shareholders. }\end{array}$ & $\begin{array}{l}\text { Operational efficiency and cost opti- } \\
\text { misation prioritised. }\end{array}$ & \\
\hline 8 & $\begin{array}{l}\text { Ownership of } \\
\text { infrastructure }\end{array}$ & The state owns the infrastructure. & The state owns the infrastructure. & $\begin{array}{l}\text { The ultimate owner of the infra- } \\
\text { structure can be the private sector. } \\
\text { This is once the debt is settled. }\end{array}$ \\
\hline 9 & $\begin{array}{l}\text { Socio-political } \\
\text { concerns/issues }\end{array}$ & $\begin{array}{l}\text { Section } 152 \text { (e) of the Constitution of } \\
\text { the Republic of South Africa man- } \\
\text { dates local government to encourage } \\
\text { the involvement of communities and } \\
\text { community organisations in the mat- } \\
\text { ters of local government. } \\
\text { Sometimes decisions on payments for } \\
\text { services are imposed because govern- } \\
\text { ment will subsidise. }\end{array}$ & $\begin{array}{l}\text { Effective engagement of communi- } \\
\text { ties is prioritised as required by law } \\
\text { because of private sector involvement } \\
\text { and levels of subsidy required as } \\
\text { prescribed by contractual obligations } \\
\text { between the parties. }\end{array}$ & $\begin{array}{l}\text { Socio-political concerns are of } \\
\text { highest priority because negative } \\
\text { outcomes can affect the bottom-line } \\
\text { of the business. If such concerns are } \\
\text { not addressed, there are chances } \\
\text { that the investor will not invest. }\end{array}$ \\
\hline 10 & $\begin{array}{l}\text { Funds following } \\
\text { functions }\end{array}$ & $\begin{array}{l}\text { Funds should follow function as } \\
\text { required by the Public Finance } \\
\text { Management Act/Municipal Finance } \\
\text { Management Act. } \\
\text { Funds for local government water } \\
\text { infrastructure should go to munici- } \\
\text { palities directly. }\end{array}$ & $\begin{array}{l}\text { Funds for either capital contribu- } \\
\text { tion or revenue subsidy should flow } \\
\text { through the municipality. }\end{array}$ & $\begin{array}{l}\text { Private sector recovers costs from } \\
\text { users either directly as per agree- } \\
\text { ment with the municipality or the } \\
\text { municipality recovers costs on } \\
\text { behalf of the private sector. }\end{array}$ \\
\hline
\end{tabular}




\begin{tabular}{|l|l|l|l|l|}
\hline \multicolumn{2}{|c|}{ TABLE 1 (continued) } \\
\hline No. & $\begin{array}{l}\text { Model } \\
\text { parameters }\end{array}$ & Parameters of the State Model & Parameters of the Hybrid Model & $\begin{array}{l}\text { Parameters of the Private } \\
\text { Sector Model }\end{array}$ \\
\hline 11 & $\begin{array}{l}\text { Technology and } \\
\text { innovation }\end{array}$ & $\begin{array}{l}\text { There is a limited chance that the } \\
\text { state will benefit from technology } \\
\text { and creative solutions. } \\
\text { There is a high chance of a private } \\
\text { sector institution using state funds to } \\
\text { develop technology that will be sold } \\
\text { back to the state at a high cost. }\end{array}$ & $\begin{array}{l}\text { There is shared creativity and techno- } \\
\text { logical innovations between the state } \\
\text { and private sector. Creative solutions } \\
\text { are explored to maximise profit and } \\
\text { achieve operational efficiency. }\end{array}$ & $\begin{array}{l}\text { Creative solutions and high levels of } \\
\text { innovation are of highest priority. } \\
\text { These are used as tools for achiev- } \\
\text { ing operational efficiency and cost } \\
\text { optimisation. }\end{array}$ \\
\hline 12 & $\begin{array}{l}\text { Open and trans- } \\
\text { parent procure- } \\
\text { ment process }\end{array}$ & $\begin{array}{l}\text { Private sector services are procured } \\
\text { through an open tender system. } \\
\text { Sometimes functionality, knowledge } \\
\text { and expertise do not drive the award- } \\
\text { ing of the tender. } \\
\text { Government carries the risk of fail- } \\
\text { ure alone and can always inject more } \\
\text { funds to correct the situation. }\end{array}$ & $\begin{array}{l}\text { Open tender system is used but the } \\
\text { private sector institutions must prove } \\
\text { that they have the capabilities to } \\
\text { deliver desired services. Failure to } \\
\text { deliver could lead to the collapse of } \\
\text { the business operations. }\end{array}$ & $\begin{array}{l}\text { Open tender system is used. } \\
\text { Private sector capabilities and } \\
\text { performance requirements are of } \\
\text { highest priority, else shareholder } \\
\text { needs will not be realised. }\end{array}$ \\
\hline
\end{tabular}

Unit should be mandated to review all local government PPP contracts and approve them after conducting due diligence (cf. NT, 1999, 2000, 2003; OECD, 2010, 2012).

There have been attempts to involve the private sector in public-private partnerships models for the creation of water services and wastewater infrastructure but not with the commitment, consistency, or the legislative protection that would encourage and protect private sector investment and encourage long-term partnerships (Moleke, 2000; Bender and Gibson, 2010; DCoG, 2010; Ruiters, 2011; Matji, 2013). However, there are several contracts with private operators for water services and wastewater infrastructure provision which include the following:

- In the Ekurhuleni Metropolitan Municipality, the Council for Scientific and Industrial Research (CSIR) was involved in a public-private partnership for biogas generation in wastewater treatment plants, i.e., the up-scaling of the technology for biogas (sludge to energy). The partners in this PPP model transaction are Barloworld Power, East Rand Water (ERWAT), CSIR, University of Pretoria and the Development Bank of Southern Africa (DBSA) as the project financier. Funds were sourced from the Green Fund. Barloworld Power will provide operation and maintenance of the generators for a period of 7 years, whereas the CSIR will continue with research and development related work and further support for 2 to 3 years after project completion. Operation and maintenance costs will be recovered from the sale of biogas produced. ERWAT owns the wastewater treatment plant or overall infrastructure in which the technology will be up-scaled.

- The City of Johannesburg took a strategic decision to corporatize its water and sanitation services (i.e. Johannesburg Water) and keep these under public management over the long term (Marin et al., 2009). This was achieved through the management contract between the City of Johannesburg and a consortium of international operators led by Suez (Marin et al., 2009). This management contract was secured through an open tender system. The primary aim of the PPP was not to transfer the utility to a private operator over the long term, but rather to leverage the expertise of an experienced operator for a few years in order to establish a viable, corporatized public water utility (Marin et al., 2009). Johannesburg Water is a product of a successful public-private partnership model in water, which evolved into a public-public partnership (i.e. City of Johannesburg Metropolitan Municipality and
Johannesburg Water). Even though Johannesburg Water was established as a municipal entity in terms of the Municipal Systems Act (DPLG, 2000), it is now operating as a publicpublic partnership model or corporatized water utility with the City of Johannesburg (CoJ) responsible for revenue, billing, and collection from consumers and Johannesburg Water (JW) is responsible for operating and maintaining both water and sanitation infrastructure (JW, 2012). The entity is also responsible for capital infrastructure development, renewal and rehabilitation to ensure uninterrupted supply of services. The entity is responsible for a water distribution network of about $11000 \mathrm{~km}, 11000 \mathrm{~km}$ of wastewater collection network and over 100 reservoirs. The entity purchases $1470 \mathrm{ML} /$ day of water from Rand Water and also treats about $980 \mathrm{ML} /$ day of wastewater (JW, 2012). Johannesburg Water has entered into a 7-year PPP arrangement for the biogas project in its Northern Works Wastewater Treatment Works. The arrangement was finalised in 2012. The contractual arrangement is structured in such a way that Johannesburg Water purchased some of the biogas-fuelled generators and the contractor invested in other required capital infrastructure. The PPP arrangement is based on the design-build-operate-maintain model for a period of 7 years. After 7 years, the contractor will hand over the infrastructure to Johannesburg Water. The contract will recover its costs from the sale of biogas generated from the operations.

- The City of Tshwane entered into a public-private partnership with Magalies Water Board, ABSA Bank and Bigen Africa, in the construction of a $60 \mathrm{ML} /$ day water purification plant. ABSA Bank was the financier, Bigen Africa was the consulting engineer responsible for the engineering design and implementation oversight, Magalies Water was charged with the responsibility of operation and maintenance of the facility after completion, and the City of Tshwane was the beneficiary (Matji, 2013). The total value of the project was R500 million. The PPP model was used as a vehicle for ringfencing bulk water and sanitation services. The contract was for a period of 20 years. Its success was based on sustainable revenue flows to the City of Tshwane.

- In the Mogalakwena Local Municipality, located within the Waterberg District Municipality of the Limpopo Province, there has been only one public-private partnership project for a period of 30 years (Matji, 2013). The PPP arrangement is for the Doorndraai pipeline from Doorndraai Dam to Mokopane town. The entire capital cost was borne by 
the mines against a 30-year agreement for the sale of final effluent by the Mogalakwena Municipality to the mines. The contractual arrangement between the mines and the Mogalakwena Municipality is currently managed jointly by the Mogalakwena Local Municipality and Lepelle Northern Water Board. Even though the PPP arrangement in the Mogalakwena Local Municipality seems to be successful, some raised contractual challenges that could compromise the municipality. The shortcomings of this PPP model arrangement are that project life-cycle costs were not factored into the contractual arrangement. Factors such as operation and maintenance costs, finance charges, and depreciation of the assets were not taken into account.

- Other potential PPP model arrangements were: (i) the bulk water services pipeline project from Flag Boshielo to Mogalakwena town which included the Department of Water Affairs, Mogalakwena Local Municipality and the mines in the Waterberg District (NT, 2013c); and (ii) the feasibility stage of the Lephalale bulk and reticulation water services infrastructure between the Lephalale Local Municipality, National Treasury and a transaction advisor (NT, 2013c).

The above-mentioned PPP models were highly successful within these provinces as a result of the following (Moleke, 2000; Bender and Gibson, 2010; DWA, 2012c; Matji, 2013):

- Well-structured public-private partnerships models for water and sanitation infrastructure can be a success, on condition that there are sufficient revenue streams, appropriate contracting models and that all parameters for the framework of PPP models are taken into account. These were initiated to improve performance, encouraging private participation and improving governance from within. PPP occurred with most having been lease contracts (or affermage) to ensure good control of the management and operations of the water and sanitation systems.

- Access to water supply for households in the concession areas increased from $47 \%$ to $94 \%$ since 2010 .

- Water and effluent quality is excellent in the systems operated by the concessionaire.

- Infrastructure operated by the concessionaire is in good order, due to a strong maintenance programme.

- The concessionaire has virtually spent $100 \%$ of the capital

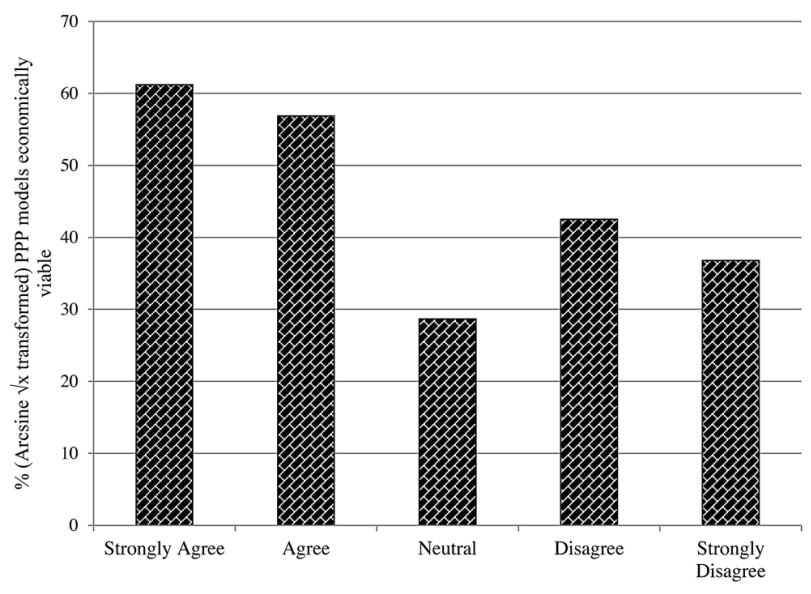

Figure 5

Percentage of respondents (arcsine $\sqrt{x}$ transformed) agreeing/ disagreeing on the economic viability of existing PPP models in the Gauteng and Limpopo Provinces of South Africa grant for extending and upgrading infrastructure in formerly under-serviced areas.

- The concessionaire has a very good employee training and development programme. This is also complemented by well qualified and competent staff members.

- Tariff levels in the concession areas are similar or lower for comparable municipalities.

\section{Key financial variables for PPP models for water services infrastructure at local government}

The results demonstrate that the key financial (awareness, success, appropriateness, (economic) viability and attractiveness) and evaluation criteria for the PPP models are independent and not associated, with $\chi^{2}>16.92, \alpha=0.05$ and $v$ (degrees of freedom $)=9$. Thus, the value of the $\chi^{2}$ test statistic $\left(\chi^{2}=\right.$ 72.203, $P<0.001$ ) exceeds the critical value of $\chi^{2}$, at $\alpha=0.05$ level of significance (Figs 5-8). This is highlighted in that approx. $52 \%$ of the respondents agreed that PPP models take into account all key variables that can affect their sustainability (Fig. 5). Some $62 \%$ of the participants believe that PPP models are economically viable or financially sustainable. On the contrary, about $30 \%$ believe that they are not economically viable because of revenue streams and the highly politicised local government environment. About $83 \%$ of the participants agreed that PPP models should be used to address operation and maintenance challenges for water and sanitation infrastructure (Fig. 6 ). Whereas some $58 \%$ of the participants strongly agreed that PPP models are appropriate vehicles for addressing the funding and financing of water services infrastructure operation and maintenance challenges at local government level (Fig. 6). However, the success of the PPP model(s) would depend on the status or condition of the infrastructure at the time of transfer or take-over. About $61 \%$ of the participants agreed that water sector PPP models are attractive to investors and financiers because of potential revenue streams from users and subsidised grants by the national government (Fig. 7).

Furthermore, the results presented in Fig. 8 demonstrate that $67 \%$ of the participants agreed that PPP models for water infrastructure are successful in funding and financing local government infrastructure. Their view is based on the municipality conducting a proper feasibility assessment, ability to collect revenue, long-term revenue streams and affordability, appropriate and transparent procurement processes and

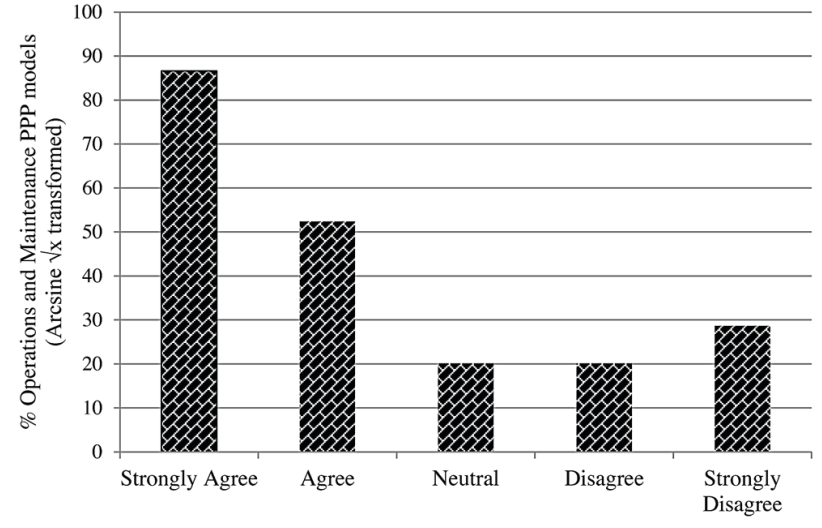

Figure 6

Percentage of respondents agreeing/disagreeing (arcsine $\sqrt{ } \boldsymbol{x}$ transformed) on the use of PPP models to address operation and maintenance in the Gauteng and Limpopo Provinces of South Africa 


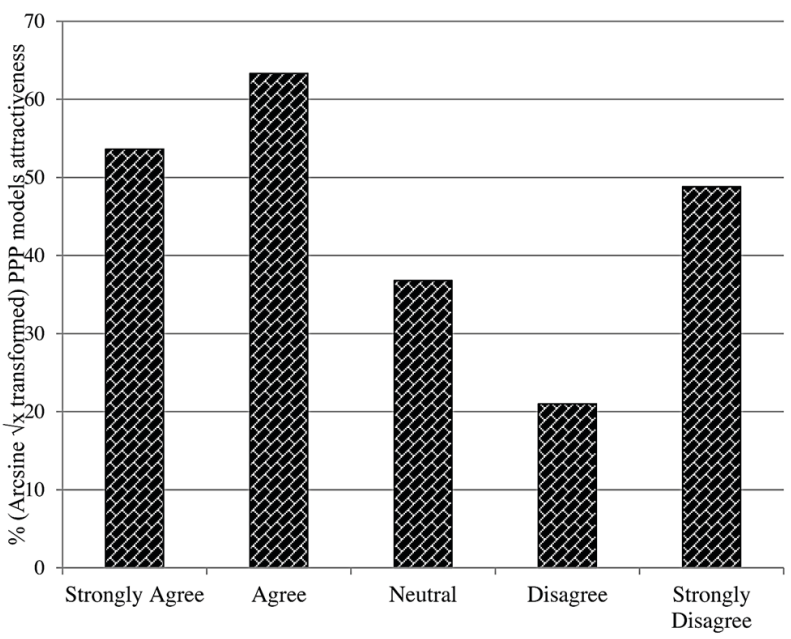

Figure 7

Percentage of respondents agreeing/disagreeing (arcsine $\sqrt{ } x$ transformed) on the water services infrastructure PPP model arrangements that are attractive to investors and financiers in the Gauteng and Limpopo Provinces in South Africa

appropriate well-structured contracts (Mokele, 2000; Bender and Gibson, 2010). Some of the respondents who disagreed believe that the current legislative framework makes it difficult for PPP arrangements to be put in place or even to function effectively. About $96 \%$ of the participants agreed that PPP models are appropriate for financing local government water infrastructure (Fig. 8). This is subject to the presence of a strong and independent water sector regulator and other regulatory mechanisms, i.e., competition commission regulation, capping of water use charges and/or tariffs (pricing), regulatory impact assessments, etc. Enforcement of legislative and regulatory frameworks should also be effective to ensure that the water users' interests are protected. The appropriateness of the model is also subject to appropriate technical and management skills in local government. Agreement was also based on the presence of an enabling legislative environment designed in such a way that it supports PPP arrangements. About $66 \%$ of the participants agreed that PPP models are appropriate vehicles for financing local government infrastructure during difficult economic conditions (Fig. 8). Some $29 \%$ of the respondents who were neutral indicated that it also depends on whether such economic conditions are not directly affecting the private sector institutions and the ability to pay for services. Thus, the above results illustrate that government must embrace and lead innovative financing, i.e., PPP funding models, as one of the preferred alternatives to deliver certain water services infrastructure projects (Figs 4-8).

\section{CONCLUSIONS}

The South African Government has recognised that new delivery models, i.e., PPP models, are required to close the infrastructure delivery gap to extend access of water and sanitation services to communities. These include the long-term growth and water services infrastructure renewal planning across the provinces, determining project priorities, and utilising the expertise in the public and private sectors to manage the implementation of water services infrastructure through innovative financing (such as PPP models). With overwhelming demand

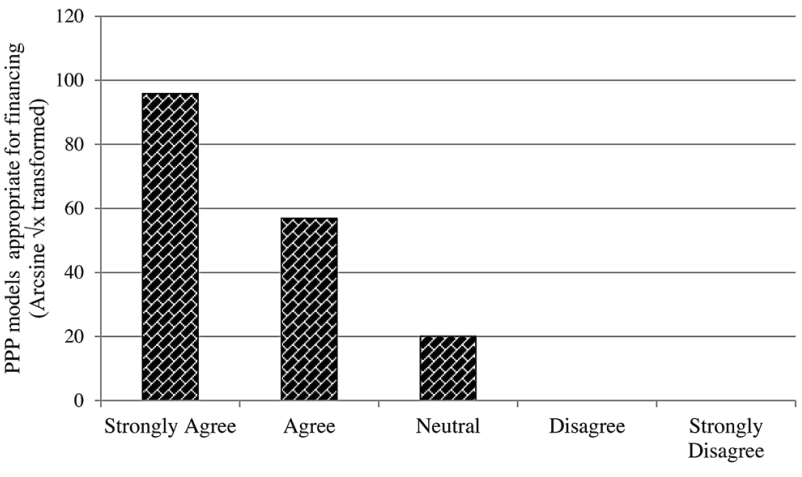

Figure 8

PPP models (arcsine $\sqrt{ } \mathrm{x}$ transformed) are appropriate for financing local government infrastructure in the Gauteng and Limpopo Provinces of South Africa

for the provision of water services infrastructure assets to be accelerated around the country, implementation of any of PPP models will go a long way towards leveraging private sector investment in economic infrastructure assets and allowing the government to recycle its capital for socio-economic needs and development, while at the same time addressing demand risk.

The research results demonstrate that the ability of the municipalities to guarantee payment of services should be considered prior to finalising the PPP arrangements. Key variables that inform PPP financing arrangements are: (i) amount of debt required; (ii) ability to repay the debt; (iii) nature of the project(s); (iv) transfer of project risks such as design, construction and maintenance; (v) value for money; and (vi) financial and socio-political uniqueness of each municipality. Buy-in of key stakeholders such as consumers or local community is crucial and without their buy-in the project(s) will fail. Costreflective tariffs are essential for the success of PPP models. National government contributions should be prioritised in municipalities where affordability is a challenge. Water services are highly politicised and this makes it difficult for municipalities to promote cost-reflective tariffs required to ensure continued operation and maintenance of the infrastructure.

\section{ACKNOWLEDGEMENT}

Financial assistance from National Treasury and CSIR to complete the project is highly appreciated. The authors express sincere gratitude to the staff members of the organisations who have contributed towards the project.

\section{REFERENCES}

AASHTO (AMERICAN ASSOCIATION OF STATE HIGHWAY AND TRANSPORTATION OFFICIALS) (1995) Innovative Transport Financing. AASHTO, Washington, DC.

ADB (ASIAN DEVELOPMENT BANK) (2008) Public-Partnership Handbook. Asian Development Bank, Manila, Philippines.

BENDER P and GIBSON S (2010) Case Study for the 10 years of the Mbombela (Nelspruit) Water and Sanitation Concession, South Africa. URL: http://www.ppp.gov.za/LegalAspects/CaseStudies/ NelspruitCaseStudyFinal20May 2010.pdf (Accessed 20 November 2013).

COLDWELL D and HERBST F (2004) Business Research. Juta, Cape Town.

DCOG (DEPARTMENT OF COOPERATIVE GOVERNANCE, SOUTH AFRICA) (2010) Strategy for Accelerating and Improving Municipal Infrastructure Provision. Department of Cooperative Governance, Pretoria. 
DPLG (DEPARTMENT OF PROVINCIAL AND LOCAL GOVERNMENT, SOUTH AFRICA) (1998) Municipal Structures Act (Act No. 117 of 1998). Government Printer, Pretoria.

DPLG (DEPARTMENT OF PROVINCIAL AND LOCAL GOVERNMENT, SOUTH AFRICA) (2000b) Municipal Systems Act (Act No. 32 of 2000). Government Printer, Pretoria.

DWA (DEPARTMENT OF WATER AFFAIRS, SOUTH AFRICA) (2010) National Non-Revenue Water Assessment. Department of Water Affairs, Pretoria.

DWA (DEPARTMENT OF WATER AFFAIRS, SOUTH AFRICA) (2011a) Strategic Plan 2010/11-2012/13. URL: http://www.dwa.gov. za/documents (Accessed 01 December 2013).

DWA (DEPARTMENT OF WATER AFFAIRS, SOUTH AFRICA) (2011b) Annual Report 2010-2011. URL: http://www.dwa.gov.za/ documents (Accessed 01 December 2013).

DWA (DEPARTMENT OF WATER AFFAIRS, SOUTH AFRICA) (2012a) Annual Performance Plan 2012/13-2014/2015. URL: http:// www.dwa.gov.za/documents (Accessed 01 December 2013).

DWA (DEPARTMENT OF WATER AFFAIRS, SOUTH AFRICA) (2012b) Institutional Re-alignment: A Strategic Framework for Institutional Re-alignment and Reform. Department of Water Affairs, Pretoria.

DWA (DEPARTMENT OF WATER AFFAIRS, SOUTH AFRICA) (2012c) Project to Revise the Pricing Strategy for Water Use Charges and Develop a Funding Model for Water Infrastructure Development and Use and a Model for the Establishment of an Economic Regulator (Contract No. WP10465). Review of Principles and Experience for Infrastructure Finance. Department of Water Affairs, Pretoria.

DWA (DEPARTMENT OF WATER AFFAIRS, SOUTH AFRICA) (2013a) National Water Resource Strategy. June 2013 Second Edition. URL: http://www.dwa.gov.za/nwrs2013 (Accessed 16 January 2014).

DWA (DEPARTMENT OF WATER AFFAIRS, SOUTH AFRICA) (2013b) Strategic Plan 2010/11-2012/13. URL: http://www.dwa.gov. za/documents (Accessed 02 December 2013).

DWA (DEPARTMENT OF WATER AFFAIRS, SOUTH AFRICA) (2013c) Annual Report 2012-2013. URL: http://www.dwa.gov.za/ documents (Accessed 02 December 2013).

DWAF (DEPARTMENT OF WATER AFFAIRS AND FORESTRY, SOUTH AFRICA) (1997a) White Paper on a National Water Policy for South Africa. URL: http://www.dwaf.gov.za/Documents/ Policies/nwpwp.pdf (Accessed 30 November 2013).

DWAF (DEPARTMENT OF WATER AFFAIRS AND FORESTRY, SOUTH AFRICA) (1997b) Water Services Act (Act 117 of 1997). Government Printer, Pretoria.

DWAF (DEPARTMENT OF WATER AFFAIRS AND FORESTRY, SOUTH AFRICA) (1998) National Water Act (Act 36 of 1998). Government Printer, Pretoria.

DWAF (DEPARTMENT OF WATER AFFAIRS AND FORESTRY, SOUTH AFRICA) (2003) Water Services Strategic Framework. Government Printer, Pretoria.

DWAF (DEPARTMENT OF WATER AFFAIRS AND FORESTRY, SOUTH AFRICA) (2004) National Water Resource Strategy of South Africa. Government Printer, Pretoria.

DWAF (DEPARTMENT OF WATER AFFAIRS AND FORESTRY, SOUTH AFRICA) (2007) Raw Water Pricing Strategy of South Africa. Government Printer, Pretoria.

DWAF (DEPARTMENT OF WATER AFFAIRS AND FORESTRY, SOUTH AFRICA) (2008) Emerging Institutional Models for Water in South Africa. Department of Water Affairs, Pretoria.

DBSA (DEVELOPMENT BANK OF SOUTHERN AFRICA) (2009) Water security in South Africa. In: Development Planning Division Working Paper Series No. 12. DBSA, Johannesburg.

DBSA (DEVELOPMENT BANK OF SOUTHERN AFRICA) (2012) Annual Report 2011/12. DBSA, Johannesburg.

EALES K (2011) Water services in South Africa 1994-2009. In: Schreiner B and Rashid H (eds.) Transforming Water Management in South Africa: Designing and Implementing a New Policy Framework. Springer, Dordrecht.

FALL M, MARIN P, LOCUSSOL A and VERSPYCK R (2009) Reforming urban water utilities in Western and Central Africa: experiences with public private partnership. In: Water Sector Board Discussion Series. World Bank, Washington DC.

GOODMAN AS and HASTAK M (2006) Infrastructure Planning Handbook: Planning, Engineering, and Economics. McGraw-Hill, New York.

INDERST G (2009) Pension Fund Investment in Infrastructure: OECD Working Papers on Insurance and Private Pensions (Report No. 32). OECD Publishing, Paris.

JW (JOHANNESBURG WATER) (2012) Annual Report 2011-2012. Johannesburg Water, City of Johannesburg, Johannesburg.

KPMG (2011) Global Infrastructure: Delivering Water Infrastructure using Private Finance. KPMG International, Switzerland.

LAITINEN I, LEINONEN J and VIRTANEN K (2010) New and Innovative Infrastructure Procurement Models - The Need for New Financing Models in Finland for Social and Economic Infrastructure. ERES, Milan, Italy.

LANG HJ and MERINO DN (1993) The Selection Process for Capital Projects. John Wiley and Sons, New York.

LEACH G (2010) Infrastructure - Mind the Gap! Institute of Directors, UK.

MARIN P (2009) Public-private partnerships for urban water utilities: A review of experiences in developing countries. In: Trends and Policy Options series \#8, PPIAF. World Bank, Washington DC.

MARIN P, MAS JP and PALMER I (2009) Using a Private Operator to Establish Corporatized Public Water Utility: The Management Contract for Johannesburg Water. Johannesburg Water, Johannesburg. http:// dx.doi.org/10.1596/978-0-8213-7956-1

MATJI MP (2013) Development of the conceptual framework for public-private partnerships model: Case studies from municipalities in the Limpopo and Gauteng Provinces, Republic of South Africa. MBL thesis, University of South Africa, Pretoria, South Africa.

MATJI MP and RUITERS C (2014) Appropriate Solutions for Operation and Maintenance Challenges of Water Services Infrastructure in South Africa. In: Proceedings of the World Congress on Engineering Asset Management, 15-19 September 2014, Pretoria, South Africa.

MATJI MP and RUITERS C (2015a) Conceptual framework for public-private partnerships model for water services infrastructure assets: case studies from municipalities in the Limpopo and Gauteng Provinces. In: Proceeding of the AMPEAK Asset Management Conference, 24-27 May 2015, Sydney, Australia.

MATJI MP and RUITERS C (2015b) Funding and financing mechanisms for infrastructure delivery: multi-sector analysis of benchmarking of South Africa against developed countries. In: Proceedings of the AMPEAK Asset Management Conference, 24-27 May 2015, Sydney, Australia.

MATTA NF and ASHKENAS RN (2003) Why good projects fail anyway. Harv. Bus. Rev. 81 (9) 109-114.

MCKENZIE R, SIQALABA ZN and WEGELIN WA (2012) The State of Non-Revenue Water in South Africa. WRC Report NO. TT 522/12. Water Research Commission, Pretoria.

MOF (MINISTRY OF FINANCE, SINGAPORE) (2012) Public-private Partnership Handbook, Version 2. Singapore, Republic of Singapore.

MOLEKE TP (2000) Public Private Partnerships and Service Delivery in Queenstown. Masters in Management thesis, University of the Witwatersrand, Johannesburg, South Africa.

MOSEKI C, TLOU T and RUITERS C (2011) National water security: Planning and implementation. In: Schreiner B and Rashid H (eds.) Transforming Water Management in South Africa: Designing and Implementing a New Policy Framework. Springer, Dordrecht.

NT (NATIONAL TREASURY, SOUTH AFRICA) (1999) Public Finance Management Act (Act No. 1 of 1999). Government Printer, Pretoria.

NT (NATIONAL TREASURY, SOUTH AFRICA) (2000) South African National Treasury PPP unit. URL: http://www.treasury. gov.za/organisation/ppp/default.htm (Accessed 26 January 2014).

NT (NATIONAL TREASURY, SOUTH AFRICA) (2003) Municipal Finance Management Act (Act No. 56 of 2003). Government Printer, Pretoria.

NT (NATIONAL TREASURY, SOUTH AFRICA) (2011a) The Estimates of National Expenditure 2011: Vote 3 Cooperative Governance and Traditional Affairs. National Treasury, Pretoria. NT (NATIONAL TREASURY, SOUTH AFRICA) (2011b) The 
Estimates of National Expenditure 2011: Vote 38 Water Affairs. National Treasury, Pretoria.

NT (NATIONAL TREASURY, SOUTH AFRICA) (2011c) The Division of Revenue Bill. Government Printer, Pretoria.

NT (NATIONAL TREASURY, SOUTH AFRICA) (2011d) Local Government Budgets and Expenditure Review: 2006/07-2012/13. URL:

http://www.treasury.gov.za/organisation/documents/default.htm (Accessed 1 November 2013).

NT (NATIONAL TREASURY, SOUTH AFRICA) (2013a) Minister of Finance Budget Speech 2013. URL: http://www.treasury.gov. za/organisation/nationalbudget/ene/default.htm (Accessed 1 November 2013).

NT (NATIONAL TREASURY, SOUTH AFRICA) (2013b) Estimates of National Expenditure 2013. URL: http://www.treasury.gov. za/organisation/nationalbudget/speech/default.htm (Accessed 1 November 2013).

NT (NATIONAL TREASURY, SOUTH AFRICA) (2013c) The State of Local Government Finances and Financial Management as at 30 June 2013: Analysis Document. URL: http://www.treasury.gov.za/ organisation/ppp/default.htm (Accessed 1 November 2013).

NT (NATIONAL TREASURY, SOUTH AFRICA) (2013d) Estimates of National Expenditure - Budget Vote 38 - Department of Water Affairs. National Treasury, Pretoria.

OECD (ORGANISATION FOR ECONOMIC DEVELOPMENT) (2012) Recommendation of the Council on Principles for Public Governance of Public-private Partnerships. OECD Publishing, Paris.

OECD (ORGANISATION FOR ECONOMIC DEVELOPMENT) (2010) Dedicated Public-private Partnership Units: A Survey of Institutional and Governance Structures. OECD Publishing, Paris. OECD (2008) Public-private Partnerships: In Pursuit of Risk Sharing and Value for Money. OECD Publishing, Paris.

RCCAO (RESIDENTIAL AND CIVIL CONSTRUCTION ALLIANCE OF ONTARIO) (2006) The Infrastructure Funding Deficit: Time to Act. RCCAO, Ontario, Canada.

ROWEY K (2009) U.S. Infrastructure Investment in a Time of Uncertainty and Global Recession. Freshfields Bruckhaus Deringer LLP, Washington DC.

RUITERS C (2011) Funding models for the financing of water infrastructure in South Africa: A framework and comparative analysis of alternatives. Unpublished MBA thesis, University of South Africa, Pretoria, South Africa.

RUITERS C (2013) Funding models for financing water infrastructure in South Africa: A framework and critical analysis of alternatives. Water SA 39 (2) 313-326. http://dx.doi.org/10.4314/wsa.v39i2.16

SIHOMBING LB (2008) Financial Innovation for Infrastructure Financing. Citra, Indonesia.

TCTA (TRANS-CALEDON TUNNEL AUTHORITY) (2012) Annual Report 2011/12. Trans-Caledon Tunnel Authority, Pretoria, South Africa.

TUSTIN DR, LIGTHELM AA, MARTINS, JH and VAN WYK H DE J (2005) Marketing Research in Practice. University of South Africa Press, Pretoria, South Africa.

UNESCAP (UNITED NATIONS ECONOMIC AND SOCIAL COMMISSION FOR ASIA AND THE PACIFIC) (2011) A Guide Book on Public-private Partnership in Infrastructure. UNESCAP, Bangkok, Thailand.

WORLD BANK (1994) World Bank Development Report: Infrastructure for Development. Oxford University Press, New York.

WORLD BANK (2010) Africa's Infrastructure: A Time for Transformation. World Bank, Washington DC. 


\section{APPENDIX 1}

Questionnaire for the developing of a conceptual framework for public-private partnerships for local government water infrastructure.

\section{SECTION A: RESEARCH OBJECTIVE NO.001}

CONDUCT A COMPARATIVE ASSESSMENT OF ALL THE PPP MODELS TO ESTABLISH SHORT-COMINGS, SUCCESSES, AND SUITABILITY TO CERTAIN ENVIRONMENTS.

\section{A. SUCCESS FACTORS OF PUBLIC-PRIVATE PARTNERSHIP MODELS IN FINANCING WATER INFRASTRUCTURE:}

A1. Public-private partnership (PPP) models are successful in financing local government water infrastructure.

\begin{tabular}{|c|c|c|c|c|}
\hline Strongly Agree & Agree & Neutral & Disagree & Strongly Disagree \\
\hline$\square$ & $\square$ & $\square$ & $\square$ & $\square$ \\
\hline
\end{tabular}

A2. PPP models are appropriate for financing local government water infrastructure.

\begin{tabular}{|c|c|c|c|c|}
\hline Strongly Agree & Agree & Neutral & Disagree & Strongly Disagree \\
\hline$\square$ & $\square$ & $\square$ & $\square$ & $\square$ \\
\hline
\end{tabular}

A3. Government should promote the use of public-private partnership models in order to fast-track water services infrastructure delivery.

\begin{tabular}{|c|c|c|c|c|}
\hline Strongly Agree & Agree & Neutral & Disagree & Strongly Disagree \\
\hline$\square$ & $\square$ & $\square$ & $\square$ & $\square$ \\
\hline
\end{tabular}

A4. Government should use public-private partnership models to address the problem of operation and maintenance of local government water infrastructure.

\begin{tabular}{|c|c|c|c|c|}
\hline Strongly Agree & Agree & Neutral & Disagree & Strongly Disagree \\
\hline$\square$ & $\square$ & $\square$ & $\square$ & $\square$ \\
\hline
\end{tabular}

\section{B. SHORT-COMINGS OF THE PUBLIC-PRIVATE PARTNERSHIP MODELS IN FINANCING WATER INFRASTRUCTURE \\ B1. In your view, what are the short-comings of the PPP models in financing local government water infrastructure?}

B2. What are regulatory or legislative obstacles that can derail financing of local government water infrastructure through PPP models in South Africa?

B3. What are socio-political issues that can derail financing of local government water infrastructure through PPP models in South Africa?

B4. What are economic factors that can discourage use of PPP models in financing local government water infrastructure through PPP models in South Africa? 


\section{SUITABILITY OF PUBLIC-PRIVATE PARTNERSHIP MODELS FOR FINANCING WATER INFRASTRUCTURE}

C1. Public-private partnership models are appropriate vehicles for financing water infrastructure during difficult economic conditions.

\begin{tabular}{|c|c|c|c|c|}
\hline Strongly Agree & Agree & Neutral & Disagree & Strongly Disagree \\
\hline$\square$ & $\square$ & $\square$ & $\square$ & $\square$ \\
\hline
\end{tabular}

C2. Public-private partnership models are appropriate vehicles for addressing operation and maintenance of local government water infrastructure.

\begin{tabular}{|c|c|c|c|c|}
\hline Strongly Agree & Agree & Neutral & Disagree & Strongly Disagree \\
\hline$\square$ & $\square$ & $\square$ & $\square$ & $\square$ \\
\hline
\end{tabular}

C3. Public-private partnership models are appropriate vehicles for addressing institutional challenges required to ensure continued maintenance of local government water infrastructure.

\begin{tabular}{|c|c|c|c|c|}
\hline Strongly Agree & Agree & Neutral & Disagree & Strongly Disagree \\
\hline$\square$ & $\square$ & $\square$ & $\square$ & $\square$ \\
\hline
\end{tabular}

C4. Public-private partnership models are socially acceptable models for financing local government water infrastructure in South Africa.

\begin{tabular}{|c|c|c|c|c|}
\hline Strongly Agree & Agree & Neutral & Disagree & Strongly Disagree \\
\hline$\square$ & $\square$ & $\square$ & $\square$ & $\square$ \\
\hline
\end{tabular}

\section{SECTION B: RESEARCH OBJECTIVE NO.002}

\section{CONDUCT AN ASSESSMENT ON VARIOUS CONTRACTUAL ARRANGEMENTS BETWEEN PRIVATE AND PUBLIC INSTI- TUTIONS INVOLVED IN THE PPP MODELS.}

D. What are the types of PPP contractual arrangements that you are aware of in Gauteng and Limpopo Provinces?

D1. Contractual arrangements for PPP models that I am aware of are yielding desired results or objectives.

\begin{tabular}{|c|c|c|c|c|}
\hline Strongly Agree & Agree & Neutral & Disagree & Strongly Disagree \\
\hline$\square$ & $\square$ & $\square$ & $\square$ & $\square$ \\
\hline
\end{tabular}

D2. In your view, what should inform contractual arrangements for PPP models in financing local government water infrastructure?

D2-1 Contractual arrangements for PPP models in Limpopo and Gauteng Provinces are taking into account all key variables which can affect the effectiveness of PPP models?

\begin{tabular}{|c|c|c|c|c|}
\hline Strongly Agree & Agree & Neutral & Disagree & Strongly Disagree \\
\hline$\square$ & $\square$ & $\square$ & $\square$ & $\square$ \\
\hline
\end{tabular}


D4. What are the minimum and maximum duration of the existing PPP contractual arrangements?

D5. How effective are the dispute resolution mechanisms for PPP models in the water sector?

\section{SECTION C : RESEARCH OBJECTIVE NO.003}

REVIEW FINANCING ARRANGEMENTS OR STRUCTURES THAT HAVE BEEN PUT IN PLACE TO GUIDE PPP MODELS IN LOCAL GOVERNMENT WATER INFRASTRUCTURE

E. What types of financing arrangements are designed to support PPP arrangements in the Gauteng and Limpopo Provinces?

E1. Financing arrangements for PPP models that I am aware of are yielding desired results and objectives.

\begin{tabular}{|c|c|c|c|c|}
\hline Strongly Agree & Agree & Neutral & Disagree & Strongly Disagree \\
\hline$\square$ & $\square$ & $\square$ & $\square$ & $\square$ \\
\hline
\end{tabular}

E2. In your view, what should inform financing arrangements for PPP models in financing local government water infrastructure?

E2-1 Financing arrangements for PPP models in Limpopo and Gauteng Provinces are taking into account affordability and revenue flows which can affect the sustainability of PPP models.

\begin{tabular}{|c|c|c|c|c|}
\hline Strongly Agree & Agree & Neutral & Disagree & Strongly Disagree \\
\hline$\square$ & $\square$ & $\square$ & $\square$ & $\square$ \\
\hline
\end{tabular}


E3. How are the finances of the existing PPP arrangements managed?

E4. What are the minimum and maximum monetary values of the existing PPP arrangements in the Limpopo and Gauteng Provinces?

E5. Water sector PPP arrangements are attractive to investors and financiers.

\begin{tabular}{|c|c|c|c|c|}
\hline Strongly Agree & Agree & Neutral & Disagree & Strongly Disagree \\
\hline$\square$ & $\square$ & $\square$ & $\square$ & $\square$ \\
\hline
\end{tabular}

\section{SECTION D : RESEARCH OBJECTIVE NO.004}

\section{DETERMINE KEY VARIABLES THAT SHOULD INFORM THE DEVELOPMENT OF A COST-EFFECTIVE PPP MODEL TO ENSURE LONG-TERM SUSTAINABILITY OF LOCAL GOVERNMENT WATER INFRASTRUCTURE}

F. What are the primary variables that should inform the structure of the PPP models in the Gauteng and Limpopo Provinces?

F1. The above-mentioned variables are taken into account in the current PPP models.

\begin{tabular}{|c|c|c|c|c|}
\hline Strongly Agree & Agree & Neutral & Disagree & Strongly Disagree \\
\hline$\square$ & $\square$ & $\square$ & $\square$ & $\square$ \\
\hline
\end{tabular}

F2. In your view, what are the key variables that should be considered when structuring PPP models in financing local government water infrastructure?

F2-1 The current PPP models that I am aware of are cost-effective and financially sustainable.

\begin{tabular}{|c|c|c|c|c|}
\hline Strongly Agree & Agree & Neutral & Disagree & Strongly Disagree \\
\hline$\square$ & $\square$ & $\square$ & $\square$ & $\square$ \\
\hline
\end{tabular}


F3. The existing PPP models are economically viable.

\begin{tabular}{|c|c|c|c|c|}
\hline Strongly Agree & Agree & Neutral & Disagree & Strongly Disagree \\
\hline$\square$ & $\square$ & $\square$ & $\square$ & $\square$ \\
\hline
\end{tabular}

F4. The current PPP models that I am aware of are socially and politically acceptable.

\begin{tabular}{|c|c|c|c|c|}
\hline Strongly Agree & Agree & Neutral & Disagree & Strongly Disagree \\
\hline$\square$ & $\square$ & $\square$ & $\square$ & $\square$ \\
\hline
\end{tabular}

